\title{
Induced Breeding of African Mud Catfish, Clarias gariepinus (Burchell 1822), using Different Doses of Normal Saline Diluted Ovaprim
}

\section{Olumuji OK* and Mustapha MK}

Department of Zoology, University of Ilorin, Ilorin, Nigeria

\begin{abstract}
African mud catfish, Clarias gariepinus is the most sought after farmed fish species in West Africa whose commercial breeding is done using expensive synthetic hormones one of which is ovaprim. The aim of the present paper is to reduce the cost of ovaprim by its dilution with normal saline in induced breeding of $C$. gariepinus. Induced breeding performance of Clarias gariepinus was evaluated using five different doses of normal saline diluted ovaprim at $0 \%, 25 \%, 75 \%$ and $100 \%$ while undiluted ovaprim served as the control. The ovaprim was administered at the rate of $0.5 \mathrm{ml}$ for each treatment per $\mathrm{kg}$ body weight of the fish, represented as treatments $A, B, C, D$ and $E$ respectively. Mean weight of stripped eggs collected were $18.45 \mathrm{~g}, 17.50 \mathrm{~g}$ and $17.25 \mathrm{~g}$ in treatments $A$, B and $C$ respectively with no significant difference $(p<0.05)$ in the values. Spawning did not occur in $D$ and $E$, thus no egg was collected. Percentage fertilization of the stripped eggs in treatments A, B and C were $88.70 \%, 87.50 \%$ and $77.38 \%$ respectively with treatment $A$ showing significant difference $(p<0.05)$ from $B$ and $C$. Percentage hatchability from the stripped eggs were $56.58 \%, 54.07 \%$ and $57.75 \%$ for treatments $A, B$ and $C$ respectively with no significant difference $(p<0.05)$ among the three treatments, while percentage survival of the fry were observed to be $40.27 \%$, $40.87 \%$ and $42.52 \%$ in treatment A, B and C. There was no significant difference $(p<0.05)$ in the survival rate among the treatments. Comparative cost benefit analysis between the control (undiluted ovaprim) and the different doses of normal saline diluted ovaprim shows that normal saline diluted ovaprim at $50 \%$ is the most cost effective. In conclusion, generic ovaprim with $50 \%$ normal saline will ensure spawning in Clarias gariepinus with high percentage hatchability of the eggs and survival of the fry.
\end{abstract}

Keywords: Clarias gariepinus; Fertilization; Hatchability; Survival; Ovaprim; Saline

\section{Introduction}

The success of fish farming enterprises is premised by the availability of good quality fish seeds. This is because as the marketable adults are sold out from the farm, young ones are provided to replenish the stock for the sustenance of the business.

Mud catfish is the most sought after fish species among fish farmers and consumers because it commands a very good commercial value in Nigerian markets [1]. In recent past, fish fingerlings are sources from the wild i.e. natural waters however, due to problems associated with wild fish seed, viz. seasonality in availability, uncertainty of species of fish seed collected, disease infestation and limited quality of harvestable fish seed, it is unreliable with respect to sustenance of commercial fish farming [2].

Artificial propagation of fish is the most promising and reliable way of ensuring availability of good quality fish seed all year round and sustainability of the aquaculture industry. It involves the use of natural (hypophysation) or synthetic hormones to induce ovulation and spawning in farmed fishes [3]. As promising as artificial propagation of mud catfish seems, one of the major constraints to fish breeders is the cost of procurement of these hormones. According to Madu [4], hormone input accounts for about $50-60 \%$ of the recurrent expenditure of a cat fish fingerling production project in Nigeria. Ovaprim for instance cost about N5, 500 per vial, Ovatide N3, 200 while the cost of a donor Mud Cat fish brood stock ranges between N1, 500 and N2, 500 [5]. Other synthetic hormones in use include Human Chorionic Gonadotrophin (HCG). Decorticosterone Acetate (DOCA), and Leutenizing Hormone Releasing Hormone [2], all of which are equally expensive.

Other workers have use non-piscine pituitary hormones such as Bull frog (Rana adspersa) [6] and the Toad (Bufo regularis) [7] in order to get a cheaper but equally effective hormone. Ovaprim is one of the most widely acceptable and readily available synthetic hormones because it has been found to be very effective [5,8]. It is a combination of SGnRHa and domperidone [9].

Saline solution is very cheap solvent (comprising $\mathrm{NaCl}$ dissolved in distilled water) in which natural hormones in pituitary are dissolved prior to administration in recipient fish [5,7]. Normal saline which is commonly used form of saline solution is prepared by dissolution of $9 \mathrm{~g}$ of $\mathrm{NaCl}$ in 1 litre of water [10]. Till now, the expensive ovaprim for the average fish breeders is used undiluted, thereby increasing the cost of fish production among fish farmers and consumers.

This study which is a pioneer study on the use of diluted ovaprim with normal saline on the induced breeding of $C$. gariepinus is aimed at comparing the effect of various doses of normal saline diluted ovaprim with undiluted ovaprim for use as hormones in induced breeding of Clarias gariepinus. This is to test the effectiveness, efficiency and efficacy of diluting the ovaprim with normal saline to induce the breeding of Clarias gariepinus.

This is in attempt to reduce the cost of ovaprim on fish breeders in the induced breeding of Clarias gariepinus and overall cost of the fish production while at the same time achieving a high spawning, hatchability and survival success of the fish.

*Corresponding author: Olumuji OK, Department of Zoology, University of Ilorin Ilorin, Nigeria, Tel: +234-806-0538972; E-mail: olumujioladehinde@gmail.com

Received March 21, 2012; Accepted May 14, 2012; Published May 23, 2012

Citation: Olumuji OK, Mustapha MK (2012) Induced Breeding of African Mud Catfish, Clarias gariepinus (Burchell 1822), using Different Doses of Normal Saline Diluted Ovaprim. J Aquacult Res Dev 3:133 doi:10.4172/2155-9546.1000133

Copyright: (c) 2012 Olumuji OK, et al. This is an open-access article distributed under the terms of the Creative Commons Attribution License, which permits unrestricted use, distribution, and reproduction in any medium, provided the original author and source are credited. 
Citation: Olumuji OK, Mustapha MK (2012) Induced Breeding of African Mud Catfish, Clarias gariepinus (Burchell 1822), using Different Doses of Normal Saline Diluted Ovaprim. J Aquacult Res Dev 3:133 doi:10.4172/2155-9546.1000133

Page 2 of

\section{Materials and Methods}

The study was carried at the laboratory of the Department of Zoology, University of Ilorin, Nigeria.

\section{Brood stock source and management}

Twenty-five (25) healthy brood stock of Mud Catfish Clarias gariepinus (Burchell, 1822) (18 females and 7 males) where purchased form Midland Aquaculture Project Limited, Ilorin, Nigeria. All brood fish were selected by external morphological characteristics using the method of Ayinla et al. [11]. Both males and females were acclimatized in separate concrete pond of $8 \times 8 \times 5 \mathrm{ft}$ for 3 weeks during which they were fed with a formulated diet of $40 \%$ crude protein containing fishmeal, toasted soya, groundnut cake, maize, bone meal, lysine methionine and Vitamin premix twice daily 7-9 am and 4-6 pm at 5\% of total fish biomass.

\section{Experimental design}

Fifteen (15) Spawning trials were carried out in all i.e. five (5) treatments with three (3) replicates of each. The five (5) treatments based on inclusion levels of undiluted generic ovaprim $0 \%$, normal saline diluted ovaprim at $25 \%, 50 \%, 75 \%$ and $100 \%$, represented as treatments $\mathrm{A}, \mathrm{B}$, $\mathrm{C}, \mathrm{D}$ and E respectively.

\section{Selection of brooder}

Fifteen (15) Female brooders with mean weight of $500 \pm 0.35 \mathrm{~g}$ were selected while 3 males having a mean weight of $2000 \pm 0.2 \mathrm{~g}$ were selected. A female is considered ripe if the abdomen is well distended and eggs oozed out freely when the abdomen was gently pressed anteroposteriorly while the male was considered ripe if the top of the genital papilla was reddish in colour [8].

\section{Hormone injection}

Selected female brooders were injected using a $2 \mathrm{ml}$ graduated syringe intramuscularly at an angle of $30-45^{\circ}$ at the dorsal fin with $0 \%$, $25 \%, 50 \%, 75 \%$ and $100 \%$ inclusion levels of normal saline. Each injected brooder was secured in different holding trough to prevent them from inflicting injury on one another. The males were not administered with hormones.

\section{Stripping and fertilization}

Injected female brooders were removed from their respective troughs after 15 hours (latency period) and stripped into dry bowls and 10 $\mathrm{g}$ of eggs were collected from each sample into hitherto labeled bowls for ease of identification. Milt of the male brooders were removed after dissecting them and the sperm collected by laceration of the milt with a clean razor blade into $25 \mathrm{ml}$ of normal saline into a Petri dish. The sperm was then used to fertilize each treatment by mixing both the eggs collected and sperm with a plastic spoon after adding equivalent volume of clean water.

\section{Incubation}

Fertilized eggs were then spread on a plastic netting substrate of 2 $\mathrm{mm}$ mesh size and placed in a 15 litre plastic trough containing about 10 litres of clean water.

\section{Estimation of percentage fertilization, hatchability and sur-} vival

Twenty eight (28) hours after fertilization, dead and unviable eggs which have turned whitish were collected after removal of the plastic netting by siphoning, counted and percentage fertilization was estimated. Percentage hatchability and survival were also calculated at $30 \mathrm{hrs}$ and the fifth $\left(5^{\text {th }}\right)$ day after hatching respectively using the method of Adebayo and Popoola [12].

\section{Water quality parameters}

$\mathrm{pH}$ and dissolved oxygen of the water were monitored daily using $\mathrm{pH}$ meter and dissolve oxygen meter respectively while mercury in glass thermometer was used to take temperature readings.

\section{Data analysis}

Data obtained were pooled for each treatment means and compared by one way ANOVA test to test significant differences $(p<0.05)$ in spawning, hatchability and survival using Duncan's multiple range test analyzed by SPSS package 2010 .

\section{Results}

The result of induced breeding of C. gariepinus using the generic undiluted ovaprim as control and four different doses of normal saline diluted ovaprim at $25 \%, 50 \%, 75 \%$ and $100 \%$ is presented in Table 1.Treatment $\mathrm{A}$ which is the control showed the highest mean weight of eggs collected than B and C, however there was no significant difference $(p<0.05)$ in the weight of eggs released in the 3 treatments. Spawning or release of eggs did not occur in treatments $\mathrm{D}$ and $\mathrm{E}$. After fertilization of the spawned eggs in the treatments, the percentage fertilization of eggs in treatment A was higher than in B and C. However treatment $\mathrm{C}$ showed a significant difference $(\mathrm{p}<0.05)$ in percentage fertilization as compared to treatments A and B. Similarly, the values of percentage hatchability from the fertilized eggs showed that treatment $\mathrm{C}$ has a relatively higher value than treatments $\mathrm{A}$ and $\mathrm{B}$, however there was no significant difference $(\mathrm{p}<0.05)$ in hatchability of the three treatments. The means of percentage survival of fry was also relatively higher in treatment $\mathrm{C}$ than in $\mathrm{A}$ and $\mathrm{B}$ but there was no significant difference $(\mathrm{p}<0.05)$ among the 3 treatments (Table 2 ).

The cost benefit analysis of the experiment is shown in Table 3. As the rate of dilution of ovaprim with normal saline increases, the cost of hormone per brood stock decreases. Also the number of fry produced per $\mathrm{ml}$ of hormone increases. Treatment $\mathrm{C}$ showed the cheapest cost with small amount of hormone used per milliliter.

\begin{tabular}{|l|l|l|l|l|l|l|l|}
\hline $\begin{array}{l}\text { Treat- } \\
\text { ments }\end{array}$ & $\begin{array}{l}\text { Mean Wt } \\
\text { before } \\
\text { stripping } \\
\text { (g) }\end{array}$ & $\begin{array}{l}\text { Mean wt } \\
\text { after strip- } \\
\text { ping (g) }\end{array}$ & $\begin{array}{l}\text { Mean } \\
\text { wt loss } \\
\text { (g) }\end{array}$ & $\begin{array}{l}\text { Mean } \\
\text { Temp. at } \\
\text { Hatching } \\
\left({ }^{\circ} \mathbf{C}\right)\end{array}$ & $\begin{array}{l}\text { Mean } \\
\text { pH }\end{array}$ & $\begin{array}{l}\text { Mean } \\
\text { D.O }\end{array}$ & $\begin{array}{l}\text { Latency } \\
\text { Period } \\
\text { (hrs) }\end{array}$ \\
\hline A & 500.35 & 481.55 & $18.45^{\mathrm{a}}$ & 24.5 & 6.50 & 6.30 & 11.30 \\
\hline B & 499.73 & 482.23 & $17.50^{\mathrm{a}}$ & 24.5 & 6.70 & 6.50 & 13.45 \\
\hline C & 500.30 & 483.05 & $17.25^{\mathrm{a}}$ & 24.5 & 6.50 & 6.80 & 27.50 \\
\hline D & 501.35 & 501.35 & 0.00 & - & & & \\
\hline E & 500.00 & 500.00 & 0.00 & - & & & - \\
\hline
\end{tabular}

Values with same superscript in the column do not differ significantly $(p<0.05)$

Table 1: Induced breeding of $C$. gariepinus using different doses of normal saline diluted ovaprim.

\begin{tabular}{|l|l|l|l|l|l|}
\hline Treatments & A & B & C & D & E \\
\hline Fertilization (\%) & $88.70^{\mathrm{b}}$ & $87.58^{\mathrm{b}}$ & $77.38^{\mathrm{a}}$ & 0.00 & 0.00 \\
\hline Hatchability (\%) & $56.38^{\mathrm{a}}$ & $54.07^{\mathrm{a}}$ & $57.75^{\mathrm{a}}$ & 0.00 & 0.00 \\
\hline Survival (\%) & $40.27^{\mathrm{a}}$ & $40.87^{\mathrm{a}}$ & $42.52^{\mathrm{a}}$ & 0.00 & 0.00 \\
\hline
\end{tabular}

Values with same superscript in a row do not differ significantly $(p<0.05)$

Table 2: Means of percentage fertilization, hatchability and survival of fry. 
Citation: Olumuji OK, Mustapha MK (2012) Induced Breeding of African Mud Catfish, Clarias gariepinus (Burchell 1822), using Different Doses of Normal Saline Diluted Ovaprim. J Aquacult Res Dev 3:133 doi:10.4172/2155-9546.1000133

Page 3 of 3

\begin{tabular}{|l|l|l|l|l|l|l|}
\hline S/N & Treatment & $\begin{array}{l}\text { \% Inclusion Level of } \\
\text { normal saline }\end{array}$ & $\begin{array}{l}\text { Cost of Hormone per } \\
\text { Brood stock (N) }\end{array}$ & $\begin{array}{l}\text { Mean No of Fry Produced } \\
\text { per treatment }\end{array}$ & $\begin{array}{l}\text { Mean Qty of Hor- } \\
\text { mone used (ml) }\end{array}$ & $\begin{array}{l}\text { No of fry produced / Cost per Fry } \\
\text { ml of Hormone }\end{array}$ \\
\hline 1 & A & 0 & 125 & 1208 & 0.25 & 4832 \\
\hline 2 & B & 25 & 93.75 & 1119 & 0.19 & 0.104 \\
\hline 3 & C & 50 & 62.50 & 1074 & 0.125 & 5889 \\
\hline
\end{tabular}

$1 \mathrm{~m}$ of ovaprim $=\mathrm{N} 500$

$\mathrm{N}=$ Naira (Unit of Nigeria currency )

Table 3: Cost benefit analysis of fry production per $\mathrm{ml}$ of ovaprim in each treatment.

\section{Discussion}

Mean weight of eggs collected from the brooders showed that normal saline diluted ovaprim at $75 \%$ and $50 \%$ is effective in induced breeding of Clarias gariepinus. It should also be noted that latency period varies directly with level of dilution of normal saline and this could be the reason why hatching does not occur at all in treatments $\mathrm{D}$ and E. This scenario has already been reported by Shepherd and Bromage [2]. The hatchability rate recorded in the experiment was similar to results obtained by Olubiyi et al. [8], where he examined the effects of various doses of ovaprim on reproductive performance of Clarias gariepinus. This work however showed that diluting generic ovaprim with normal saline at $75 \%$ and $50 \%$ could also result in the production and hatchability of eggs as well as survival of fry which compared well with undiluted ovaprim. Thus, it shows that normal saline could enhance the production, hatchability of eggs and survival of fry. The percentage survival was however relatively lower compared to results obtained by Nwokoye et al. [5], and this could be attributable to the size of the receptacle (tank) in which the experiment was conducted which was relatively smaller and also more eggs were fertilized and the tank was not power-aerated. The high hatchability and survival recorded in treatment $\mathrm{C}$ was due to the high effects of physico-chemical parameters such as high concentration of dissolved oxygen $[9,13,14]$. Comparing the costs in the 3 treatments, it is evident that treatment $\mathrm{C}$ with $50 \%$ inclusion of normal saline diluted ovaprim is highly cost effective, reducing the cost of the hormone used by half.

\section{Conclusion}

From the research, normal saline diluted ovaprim at $50 \%$ inclusion level will induce breeding in Clarias gariepinus with similar effectiveness, efficiency and efficacy comparable to generic ovaprim. With this, $50 \%$ of the cost incurred on the hormone can be saved without having to jeopardize its performance with respect to induce breeding of Clarias gariepinus. This will reduce the cost to farmers as well as ensuring a high production of C. gariepinus more at an affordable cost.

\section{References}

1. Oladosu GA, Ayinla OA, Adeyemo AA, Yakubu AF, Ajani AA (1993) Comparative study of reproductive capacity of the African catfish species Heterobranchus bidorsalis, Clarias gariepinus and their hybrid. African Regional Aquaculture Centre Tech 92: 1-5.

2. Shepherd CJ, Bromage NR (1988) Intensive fish farming. Blackwell science Ltd., 404.

3. Viveen WJAR, Ritcher CJJ, Van Oordt PGWJ, Janseen JAL, Huisman EA (1985) Practical manual for the culture of the African Catfish Clarias gariepinus. Section for Research and Development Co-operation, the Hague, Netherlands, 121

4. Madu CT (2006) The effects of brood stock size on the economy of catfish (Clarias anguillaris) fry production using the hormone induced natural breeding technique. J Aquat Sci 21: 19-22.

5. Nwokoye CO, Nwuba LA, Eyo JE (2007) Induced propagation of African Clariid Catfish Heterbranchus bidorsalis (Gerffrey Saint Hillaries, 1809) using synthetic and homoplastic hormones. African Journal of Biotechnology 6: 2687-2693.
6. Salami AA, Balogun AM, Fagbemi S, Edibite L (1993) Utilization of Non-piscine pituitary extract in the breeding of Clarias gariepinus. Proceedings of the $10^{\text {th }}$ Annual Conference of Fisheries Society of Nigeria (FISON), UNAAB, Abeokuta, Nigeria.

7. Fagbenro OA, Salami AA, Sydenham DHJ (1993) nduced Ovulation and Spawning in the Catfish, Clarias isheriensis, Using Pituitary Extracts from Non-piscine Sources. Journal of Applied Aquaculture 4: 15-20.

8. Olubiyi OA, Ayinia OA, Ayinia OA, Adeyemo AA (2005) The effects of various doses of ovaprim on reproductive performance of the African catfish Clarias gariepinus (Burchell) and Heterobranchus longifilis (Valenciennes). African Journal of Applied Zoology and Environmental Biology 7: 101-105.

9. Sahoo SK, Giri SS, Chandra S (2008) Induced spawning of Clarias batrachus (Linn): effect of ovaprim doses and latency periods on the weight of stripped eggs and ovary. Asian fisheries science 21: 333-338.

10. Madu CT (1989) Hatchery management of the Mudfish, Clarias anguillaris (L). PhD Thesis University of Jos, Nigeria, 215.

11. Ayinla OA, Kayode O, Idoniboye-Obu TIE, Oresegun A, Adindu VE (1994) Use of tadpole meal as substitute for fishmeal in diet of Heterobranchus bidorsalis (Geofrey St. Hillaire, 1809). Journal of Aquaculture in the Tropics 9: 25-33.

12. Adebayo OT, Popoola OM (2008) Storage Period; its effect on efficacy of nonpiscine (frog) Hormone used in inducing ovulation in African Catfish (Clarias gariepinus Burchell, 1822). International Journal of Zoological Research 4: 124-128.

13. Nwadukwe FO (1993) Inducing oocyte maturation, ovulation and spawning in the African catfish, Heterobranchus longifilis Valenciennes (Pisces: Clariidae), using frog pituitary extract. Aquaculture Research 24: 625-630.

14. Odunze FC (2004) Environmentally induced physiological responses that determined fish survival and distribution: A review: $19^{\text {th }}$ conference proceedings of Fisheries Society of Nigeria Ilorin, Nigeria, $429-435$. 